\title{
Article
}

\section{Nirvana or Never-Never Land: Does heutagogy have a place in coach development?}

Stoszkowski, J., and Collins, D.

Available at http://clok.uclan.ac.uk/19818/

Stoszkowski, J., ORCID: 0000-0002-1968-5770 and Collins, D. ORCID: 00000002-7601-0454 (2017) Nirvana or Never-Never Land: Does heutagogy have a place in coach development? International Sport Coaching Journal, 4 (3). pp. 353-358. ISSN 2328-918X

It is advisable to refer to the publisher's version if you intend to cite from the work. http://dx.doi.org/10.1123/iscj.2017-0001

For more information about UCLan's research in this area go to http://www.uclan.ac.uk/researchgroups/ and search for < name of research Group>.

For information about Research generally at UCLan please go to http://www.uclan.ac.uk/research/

All outputs in CLoK are protected by Intellectual Property Rights law, including Copyright law. Copyright, IPR and Moral Rights for the works on this site are retained by the individual authors and/or other copyright owners. Terms and conditions for use of this material are defined in the policies page.

\section{CLoK}

Central Lancashire online Knowledge www.clok.uclan.ac.uk

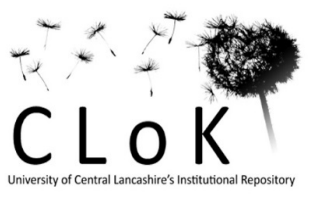


2 Nirvana or Never-Never Land: Does Heutagogy have a place in Coach Development? 3

4 John Stoszkowski* and Dave Collins Institute of Coaching and Performance, University of 5 Central Lancashire, U.K.

6

$7 \quad *$ Corresponding author. School of Sport and Wellbeing, The University of Central

8 Lancashire, Preston, UK, PR1 2HE, Tel 01772895702.

9 Email: JRStoszkowski@uclan.ac.uk; DJCollins@uclan.ac.uk

10

11

12

13 
Abstract

15 Heutagogic learning is characterized by the notion of human agency. Power and autonomy

16 are placed firmly in the hands of the learner, who takes responsibility for, and control of,

17 what they will learn, when it will be learnt and how it will be learnt. As a result, if

18 sufficiently reflexive, heutagogic learners are said to acquire both competencies (knowledge

19 and skills) and capabilities (the capacity to appropriately and effectively apply one's

20 competence in novel and unanticipated situations). The complex and dynamic environment of

21 sports coaching, coupled with coaches' apparent preference for informal self-directed

22 learning methods (as opposed to more formalised educational settings), would therefore seem

23 perfect for its application. In this insights paper, we aim to stimulate debate by providing a

24 critical overview of the heutagogic method and consider it against the nature of coaching

25 skill. In tandem, we identify some essential pre-conditions that coaches might need to

26 develop before heutagogic approaches might be deployed effectively in coach education.

27 Keywords: coach learning; coach education; self-determined learning; 
Nirvana or Never-Never Land: Does Heutagogy have a place in Coach Development?

30

Since its inception as an extension of andragogy (Hase \& Kenyon, 2000), heutagogy, or the study of self-determined learning ("heut" is derived from the Greek word for "self"), has attracted increasing attention in wide a variety of education contexts including clinical nursing practice (Bhoyrub, Hurley, Neilson, Ramsay, \& Smith, 2010), teacher education (Ashton \& Newman, 2006), higher education (Canning, 2010), workplace e-Learning (Canţer, 2012) and engineering (Gazi, 2014). At face value, there is a lot to like. The heutagogic learning process is characterised by highly autonomous learners taking personal responsibility for, and control of, what will be learnt, when it will be learnt and how it will be learnt. This continuous process occurs in real-time as the learner (if sufficiently reflexive) becomes aware of deficits in their current skills, knowledge and/or capabilities through interactions with their environment, and devises their own strategies for bridging the gap (Hase \& Kenyon, 2001; Hase, 2009). Heutagogic learners acquire not just competencies (knowledge and skills) but capabilities (the capacity to appropriately and effectively apply one's competence in novel and unanticipated situations). As such, the complex and dynamic environment of coaching (e.g., Collins \& Collins, 2014) would seem perfect for its application. When considered in tandem with the apparent preference of coaches to learn through informal self-directed methods rather than more formalized educational settings (Stoszkowski \& Collins, 2015), the approach of learner determining the learning path and being "the major agent in their own learning" (Hase \& Kenyon, 2007, p. 112) seems to offer a perfect solution. The reportedly successful use of heutagogy in teacher education (Ashton \& Newman, 2006; Ashton \& Elliott, 2007), clearly an extremely close parallel, seems to clinch it. This is the approach coach education has been waiting for! 
Before we rush to cancel coach education courses however, there may be some issues

which need consideration. Heutagogic enthusiasts justifiably state the need for a level of maturity and independence in the learner; characteristics which are also central to the application of andragogic approaches (Knowles, 1975). It seems to us that some level of base knowledge, together with an openness and commitment to self-reflection would also be essential prerequisites. Accordingly, and in full acknowledgement of the very attractive features which a heutagogic approach can offer, we wanted to provide a critical consideration of the method. Therefore, we present an evaluative reflection in four sections. Firstly, we offer more detail on the heutagogic approach as a continuum of andragogy. Secondly, we consider literature which has looked at the essential pre-conditions which coaches need to develop. Thirdly, we consider the nature of coaching skill, to see whether, or at what stage, heutagogic approaches may be usefully deployed. Finally, our concluding section proposes some structures which may already use the approach to good effect.

\section{Heutagogy: A Rough Guide}

Heutagogy has its roots in a broad range of humanistic theories and learning approaches including phenomenology (Rogers, 1969), action learning (Kemmis \& McTaggart, 1998), connectivism (Dron \& Anderson, 2014), systems thinking (Akoff \& Emery, 1972), complexity theory (Waldrop, 1992), double loop learning, (Argyris \& Schön, 1978) and transformational learning (Mezirow, 1994). It is also underpinned by the ideas of constructivist theorists (e.g., Bruner, 1960; Dewey, 1938; Freire, 1972; Piaget, 1973; Vygotsky, 1978), who purport that learners construct meaning from their own experiences. Hase and Kenyon (2000), who first coined the term, envisaged heutagogy as a natural extension of the earlier "-gogies" of pedagogy (i.e., the art or science of educating children, Hinchey, 2004) and andragogy (i.e., the art and science of helping adult learners, Knowles, 1975). Typically, the former acknowledges teachers' power and perceives them as a 
knowledge "transmitter" (see Table 1), with learners framed as passive recipients of this knowledge in compulsory learning environments, whilst the latter, although still tutormanaged, assumes greater learner competence and independence and encompasses more selfdirected and problem-based learning (Anderson, 2013; Knowles, 1975). Although pedagogy and andragogy both emphasize the acquisition of knowledge and skills (competencies), heutagogy is said to go one step further by taking into account the complexity of learning and emphasizing the associated importance of developing the capabilities of the learner in addition to competencies (Hase \& Kenyon, 2000; Hase, 2009).

A key tenet of the heutagogic paradigm is a belief in the notion of human agency, with power and autonomy placed firmly in the hands of the learner (Ashton \& Newman, 2006). As in an andragogic approach, the role of the educator is positioned as that of a “learning facilitator" who guides the development of ideas and learners' learning capabilities, as opposed to transmitting the wisdom of others (Ashton \& Elliot, 2007; Ashton \& Newman, 2006); however, they fully surrender ownership of the learning path and process to the learner (Blaschke, 2012). Heutagogy is said to recognize that "people learn when they are ready and that this is most likely to occur quite randomly, chaotically and in the face of ambiguity and need" (Hase \& Kenyon, 2003, p. 3-4). As such, heutagogic learning is said to be fundamentally emergent, dynamic and non-linear, with each learner's path potentially unique (Gazi, 2014; Hase, 2009). Moreover, according to Hase and Kenyon (2001), heutagogy recognizes the need for flexibility in learner-generated contexts and content, as "the teacher provides resources but the learner designs the actual course he or she might take by negotiating the learning." Heutagogy, therefore, promotes the processes and strategies that learners engage with to further their understanding, not only of the subject or topic they are studying, but also of themselves as learners. Importantly then, it is more than "just" self- 
directed skills and knowledge acquisition, but an understanding of the stimuli learners need in order to learn effectively (Canning \& Callan, 2010; Gazi, 2014).

Learners educated within a heutagogic framework are said to benefit by becoming better critical thinkers and problem solvers, they develop confidence in their perceptions and learn to question their beliefs, values, assumptions and interpretations of reality from their position of competence (Ashton \& Newman, 2006); they are able to create their own flexible curriculum and negotiate and plan their own assessment tasks (Hase \& Kenyon, 2001; 2007); they are motivated to research their own interests independently, are able to apply their multidisciplinary learning to practice and to their personal philosophy, and embrace collaborative learning and knowledge sharing (Canning, 2010); and they become self-aware and able to articulate feelings, experiences and ideas (Canning \& Callan, 2010). Based on these characteristics, heutagogy has been positioned in the literature as being ideally suited to the highly complex, often ambiguous, unpredictable and information rich world in which learning now takes place (Hase, 2009). Similarly, it is purported to be more suitable than "traditional" educational methods for recognizing and developing the complex array of skills and characteristics professionals need for the modern workplace (Hase \& Kenyon, 2000); indeed, Hase and Kenyon (2000) suggest that the modern workplace is "no place for the inflexible, the unprepared, and the ostrich with its head in the sand" (p. 5). Nevertheless, we believe there are some important caveats and pre-conditions that coaches will require if they if they are to garner optimum benefit from a heutagogic approach to their development, which we turn to in the following section.

\section{Characteristics of Self-Driven Development}

Reflecting statements made earlier in the paper, we suggest that a strong case exists for an essential set of precursory skills, attitudes or characteristics (cf. the idea of capabilities highlighted earlier) which are essential if the desirable benefits of heutagogy are to be 
127 realised. We would intuitively suggest that there are several such precursors, some of which seem to us to be sometimes explicit but always clearly implicit within the writings of heutagogic theorists and/or supporters. For our purposes here, however, we will focus on two:

130 firstly, the important attribute of emotional maturity and secondly, the adult learner's

131 perceptions of knowledge and the learning process itself. Emotional maturity or EM relates to how an individual perceives him or herself.

133 Defined as a "higher state of consciousness, guided by what one senses, feels, and intuits, and 134 one's heart" (Vajda, 2013, p.37), EM also relates to how well one is able to respond to 135 situations, control emotions, and behave in an "adult" manner. Accordingly, this attribute has 136 been suggested as essential for self-directed learners, giving them the capacity to respond 137 positively and reflect in a less ego-involved fashion when new and challenging perspectives 138 are apparent. For our present purpose, EM could perhaps be seen as a way to operationalise open-mindedness in the face of views which contradict one's own. In any case, there are

140 some interesting if preliminary findings for the construct, with recent work highlighting the 141 positive correlations between EM and adult learning scores (Bhagat, Haque, Bakar, Husain, 142 \& Khairi, 2016). Other data show more positive performance outcomes for students higher in 143 EM (Singh, Kaur, \& Dureja, 2012). In summary, EM would seem to offer a good 144 representation of the attributes and attitude needed for someone to engage effectively in 145 heutagogy.

146 Our second exemplar precursor comes from the well-established work of Entwistle 147 and colleagues. In a seminal paper, Entwistle and Peterson (2004) examined how perceptions 148 of knowledge and learning acted to influence behaviour in adult learners; in their case, higher 149 education students. At one end of their developmental continuum, dualistic views of 150 knowledge were associated with a perception of learning as the storage of facts. At the other, 151 a transition only completed by a subset of students, a relativistic view of knowledge led 
152 students to "seeing things in a different way" (p. 409) as the outcome of learning. Such

153 differences in perception have already been shown to impact on coach behaviour. For

154 example, Collins, Abraham and Collins (2012) demonstrated that experienced coaches at the

155 dualistic end were much less likely to source coach education opportunities than those at the

156 relativist end of the continuum. It also seemed an important factor in the coach's drive to seek

157 out, or even willingness to consider, new ideas. As such, a coach's placement on this

158 continuum would seem to be another important mediator for involvement in and impact of

159 heutagogic behavior.

\section{Stages of Evolution in Coaching Skill}

161 So, given that individual characteristics may impact of the efficacy or even likelihood

162 of heutagogy, would the coach's level and/or nature of development also act as a mediating

163 influence? Research has already highlighted how the training and accreditation methods

164 employed may influence attitude towards innovation (Collins, Martindale, Burke \&

165 Cruickshank, 2015). Of particular relevance, the use of an expertise-focused approach,

166 employing the ideas of Professional Judgement and Decision Making (PJDM - Abraham \&

167 Collins, 2011; Collins \& Collins, 2014) would seem to explicitly encourage a heutagogic

168 approach due to its emphasis on reflection, innovation and considering alternatives.

169 Such benefits should accrue for coaches at all levels, were such an approach to be

170 employed. Given the current predominance of competency-based assessment, however, it

171 may be that appropriate reflection and seeking for innovation will only "kick in" at higher

172 levels of qualification. As a consequence, heutagogic approaches may be more impactful with

173 more senior coaches. We would hope not, of course. Certainly, if all reflective coaches are

174 seen as experimenters (Schön, 1983) then heutagogy will work with all.

175 There is further evidence of the self-directed development approach implicit within

176 the work of Collins, Collins and Carson (2016) on intuition. Their examination of high level 
177 coaches in adventure sports and rugby demonstrated the use of Type 1 and Type 2 thinking

178 (Kahneman, 2011) when quick-fire decisions were taken. As a matter of course, the coaches

179 in this study tended to reflect back on quick decisions, an action often leading them to seek

180 out new areas of knowledge to ensure both current and future decisions were optimised.

181 Taken with earlier ideas, this suggests that the self-driven search for new knowledge which

182 characterises heutagogy may be a characteristic of higher level coaches, or at least (reflecting

183 the previous section) those with the right precursive attributes as well. Whether this is as a

184 result of individual tendency, experience or training awaits investigation.

\section{Conclusion}

186 We hope to have offered a reasoned argument that heutagogy could be a useful part of

187 the coach development diet but, perhaps, only for certain individuals who have acquired a

188 level of maturity, attitude and approach which equips them for it. There is certainly evidence

189 for what such a level would comprise of. For example, the importance of metacognition to

190 coaching has already been shown, especially in hyper-dynamic environments such as

191 adventure sports (Collins, Carson \& Collins, 2016). It would seem that the challenges

192 inherent in adventure sports coaching may "encourage" or even require coaches to take a

193 more heutagogic approach than their peers in more traditional sporting paradigms.

194 There is also evidence that better preparatory education may facilitate heutagogy.

195 Work on the use of online blogs as a tool in coach development has shown that, whilst some

196 benefits can be gained by using the approach with student coaches, these benefits are greater

197 and more impactful once certain educational inputs have been completed (Stoszkowski \&

198 Collins, 2015b; Stoszkowski, Collins \& Olsson, 2015).

199 Finally, there are already programmes of study which incorporate many elements of

200 the heutagogic approach. The Professional Doctorate in Elite Performance (UCLan, 2016)

201 offers coaches and others an opportunity to self-initiate study in a chosen area of vocational 
interest, albeit that subsequent outputs must be externally structured to meet the requirements of the degree. We would suggest that a totally heutagogic programme leading to an academic award is some way off. However, it is good to report the successes associated with this first application of its principles.

In concluding our critical overview of heutagogy, we should reiterate some pragmatic points. Firstly, whilst there will always be some individuals who will employ this approach, we would suggest that only some will optimally benefit from it. We do feel that changes to the educational and accreditation processes employed may generate some extremely beneficial enhancement of individual openness and curiosity (Collins et al., 2015) and that

211 this, in turn, would lead to a more heutagogic environment. That is, however, a more multi-

212 faceted argument than is appropriate here. Secondly, we would argue that there will always

213 be a need for some tutorial or leadership role, making the exercise closer to andragogy than

214 heutagogy in its purest sense. After all, there are so many urban myths and confusions which

215 permeate even the most learned of professions: a situation which led Kirschner and van

216 Merriënboer (2013) to observe of the education profession whether "learners really know

217 best" (p. 169). Of relevance to our present purpose, this paper was somewhat critical of the

218 learner as self-educator approach. Perhaps we are best closing with a recent quote from an

219 author writing on heutagogy: "learners will require ongoing instructor guidance and support

220 throughout the learning process if they are to develop the capability of self-direction"

221 (Blaschke, 2012, p. 66). So, in summary, although not an unachievable never-never land, it would seem that nirvana may still be someway off! 
Abraham, A., \& Collins, D. (2011). Taking the next step: Ways forward for coaching science. Quest, 63, 366-384.

Ackoff, R. L., \& Emery, F. E. (1972). On purposeful systems. Chicago: Aldine-Atherton.

Anderson, W. (2013). Independent learning. In M. G. Moore \& W. G. Anderson (Eds.), Handbook of distance education (pp. 86-103). Mahwah, NJ: Lawrence Erlbaum.

Argyris, C., \& Schön, D. (1978). Organizational learning: A theory of action perspective. Reading, MA: Addison-Wesley.

Ashton, J., \& Elliott, R. (2007). Juggling the balls - study, work, family and play: Student perspectives on flexible and blended heutagogy. European Early Childhood Education Research Journal, 15(2), 167-181.

Ashton, J., \& Newman, L. (2006). An unfinished symphony: 21st century teacher education using knowledge creating heutagogies. British Journal of Educational Technology, $37(6), 825-840$.

Bhagat, V., Haque, M., Bakar, Y., Husain, R., \& Khairi, C-M. (2016). Emotional maturity of

Bhoyrub, J., Hurley, J., Neilson, G. R., Ramsay, M., \& Smith, S. (2010). Heutagogy: An medical students impacting their adult learning skills in a newly established public medical school at the east coast of Malaysian Peninsula. Advances in Medical Education and Practice, 7, 575-584.

Blaschke, L. M. (2012). Heutagogy and lifelong learning: A review of heutagogical practice and self-determined learning. International Review of Research in Open and Distance Learning, 13(1), 56-71.

247 Bruner, J. (1960). The process of education. Cambridge, MA: Harvard University Press. 
248 Canning, N. (2010). Playing with heutagogy: Exploring strategies to empower mature learners in higher education. Journal of Further and Higher Education, 34(1), 59-71.

Canning, N., \& Callan, S. (2010). Heutagogy: Spirals of reflection to empower learners in higher education. Reflective Practice, 11(1), 71-82.

Canţer, M. (2012). E-heutagogy for lifelong e-learning. Procedia Technology, 1, 129-131.

Collins, D., Abraham, A., \& Collins, R. (2012). On vampires and wolves - Exploring and countering reasons for the differential impact of coach education. International Journal of Sport Psychology, 43, 255-271.

Collins, L., \& Collins, D. (2014). Integration of in-action reflective practice as a component of professional judgement and decision making in high level adventure sports coaching practice. Journal of Sports Sciences, 33(6), 622-633.

Collins, D., Martindale, A., Burke, V., \& Cruickshank, A. (2015). The illusion of competency versus the desirability of expertise: Seeking a common standard for support professions in sport. Sports Medicine, 45(1), 1-7.

Collins, L., Carson, H. J., \& Collins, D. (2016). Metacognition and professional judgement and decision making in coaching: Importance, application and evaluation. International Sports Coaching Journal, 3(3), 355-361.

Collins, D., Collins, L., \& Carson, H. (2016). "If it feels right, do it": Intuitive decision making in a sample of high-level sport coaches. Frontiers in Psychology, 7, 504.

267 Dewey, J. (1938). Experience and education. New York, NY: Macmillan.

268 Dron, J., \& Anderson, T. (2014). Teaching crowds: Learning and social media. Edmonton: Athabasca University Press.

Ekoto, C. E., \& Gaikwad, P. (2015). The impact of andragogy and learning satisfaction of graduate students. American Journal of Educational Research, 3(11), 1378-1386. 
272 Entwistle, N. J., \& Peterson, E. R. (2004). Conceptions of learning and knowledge in higher education: Relationships with study behaviour and influences of learning environments. International Journal of Educational Research, 41, 407-428.

Freire, P. (1972). Pedagogy of the oppressed. Harmondsworth, UK: Penguin.

Gazi, Y. (2014). Issues surrounding a heutagogical approach in global engineering education, paper presented at the 121st ASEE Annual Conference and Exposition, Indianapolis. Retrieved from http://www.asee.org/public/conferences/32/papers/9938/view.

Hase, S. (2009). Heutagogy and e-learning in the workplace: Some challenges and opportunities. Journal of Applied Research in Workplace E-learning, 1(1), 43-52.

Hase, S., \& Kenyon, C. (2000). From andragogy to heutagogy. Ultibase Articles. Australia: Southern Cross University.

Hase, S., \& Kenyon, C. (2001). Moving from andragogy to heutagogy: Implications for VET. Proceedings of Research to Reality: Putting VET Research to Work. Adelaide, SA: Australian Vocational Education and Training Research Association (AVETRA).

Hase, S., \& Kenyon, C. (2003). Heutagogy and developing capable people and capable workplaces: Strategies for dealing with complexity. Proceedings of the Changing Face of Work and Learning Conference. Edmonton, AB: University of Alberta.

Hase, S., \& Kenyon, C. (2007). Heutagogy: A child of complexity theory. Complicity: An international journal of complexity and education, 4(1), 111-118.

Hinchey, P. (2004). Becoming a critical educator: Defining a classroom identity, designing a critical pedagogy. Oxford, UK: Peter Lang.

Kemmis, S., \& McTaggart, R. (Eds.). (1988). The action research planner (3rd ed.). Geelong, Victoria: Deakin University Press.

Kirschner, P. A., \& van Merriënboer, J. G. J. (2013). Do learners really know best? Urban legends in education. Educational Psychologist, 48(3), 169-183. 
297 Khaneman, D. (2011). Thinking fast and slow. New York: Farrar, Strauss and Giroux.

298 Knowles, M. (1975). Self-directed learning: A guide for learners and teachers. Newmarket, 299 ON: Prentice Hall.

300 Mezirow, J. (1994). Understanding transformation theory. Adult Education Quarterly, 44(4), 222-232.

302 McKeown, L. (2011). Pedagogy, Andragogy, Heutagogy compared [Blog]. Retrieved from http://www.blog.lindymckeown.com/?p=52

304 Piaget, J. (1973). To understand is to invent. New York, NY: Grossman.

305 Rogers, C. R. (1969). Freedom to learn. Columbus, OH: Merrill.

306 Schön, D. (1983). The reflective practitioner: How practitioners think in action. San

$307 \quad$ Francisco, CA: Harper Collins.

308 Singh, D., Kaur, S., \& Dureja, G. (2012). Emotional maturity differentials among university students. Journal of Physical Education and Sport Management, 3(2), 41-45.

310 Stoszkowski, J., \& Collins, D. (2015a). Sources, topics and use of knowledge by coaches. Journal of Sport Sciences, 34(9), 794-802.

312 Stoszkowski, J., \& Collins, D. (2015b). Using shared online blogs to structure and support informal coach learning. Part 1: A tool to promote reflection and communities of practice? Sport, Education and Society, 22(2), 247-270.

Stoszkowski, J., Collins, D., \& Olsson, C. (2015). Using shared online blogs to structure and support informal coach learning. Part 2: The participants' view and implications for coach education. Sport, Education and Society, 22(3), 407-425.

UCLan (2016). The Professional Doctorate in Elite Performance. Downloaded from http://www.uclan.ac.uk/courses/professional_doctorate_elite_performance.php. 12 $2^{\text {th }}$ December. 
321 Vajda, P. (2013). Becoming a better you: Who you are vs. who you think you are. New 322 York, NY: Infinity.

323 Vygotsky, L. S. (1978). Mind in society: The development of higher psychological processes. Cambridge, MA: Harvard University Press.

325 Waldrop, M. (1992). Complexity: The emerging science at the edge of order and chaos. London, UK: Penguin.

327

328

329

330

331

332

333

334

335

336

337

338

339

340

341

342

343

344 
Table 1

The Pedagogy-Andragogy-Heutagogy Continuum

\begin{tabular}{|c|c|c|c|}
\hline Aspect & Pedagogy & Andragogy & Heutagogy \\
\hline Locus of control & $\begin{array}{l}\text { Teacher directs } \\
\text { what, how and when } \\
\text { anything is learned }\end{array}$ & Self-directed & Self-determined \\
\hline Level of cognition & Cognitive & Meta-cognitive & Epistemic \\
\hline $\begin{array}{l}\text { Developmental } \\
\text { emphasis }\end{array}$ & Acquisition & Competency & Capability \\
\hline Role of teacher & $\begin{array}{l}\text { Designs the learning } \\
\text { process, imposes } \\
\text { material }\end{array}$ & Enabler or facilitator & $\begin{array}{l}\text { Develop the } \\
\text { learner's capability }\end{array}$ \\
\hline Focus of learning & $\begin{array}{l}\text { Subject centred, } \\
\text { prescribed } \\
\text { curriculum and } \\
\text { planned sequences }\end{array}$ & $\begin{array}{l}\text { Task or problem } \\
\text { centred }\end{array}$ & $\begin{array}{l}\text { Pro-active context } \\
\text { shaping }\end{array}$ \\
\hline Reasons for learning & $\begin{array}{l}\text { Learn in order to } \\
\text { advance to next } \\
\text { stage }\end{array}$ & $\begin{array}{l}\text { Learn when they } \\
\text { experience a need to } \\
\text { know }\end{array}$ & $\begin{array}{l}\text { Learning is non- } \\
\text { linear and based on } \\
\text { identification of the } \\
\text { potential to learn in } \\
\text { novel situations }\end{array}$ \\
\hline Learner's experience & Little worth & Important & Greatly important \\
\hline
\end{tabular}

Adapted from Blaschke (2012), Ekoto and Gaikwad (2015) and McKeown (2011) 